\title{
Peripheral osteoma of the mandible
}

\author{
Vijayendranath Nayak, ${ }^{1}$ Prasanna Kumar Rao, ${ }^{2}$ Raghavendra Kini, ${ }^{2}$ Ujwala Shetty ${ }^{2}$
}

${ }^{1}$ Oral Medicine and Radiology, Melaka Manipal Medical College, Bukit Baru, Melaka, Malaysia

${ }^{2}$ Oral Medicine and Radiology, AJ Institute of Dental Sciences, Mangalore, Karnataka, India

\section{Correspondence to} Dr Vijayendranath Nayak; drnayakomr@gmail.com

Accepted 16 September 2020

\section{DESCRIPTION}

A 30-year-old male patient made a visit to our clinic with a chief complaint of painless swelling in the lower left back tooth region for 3 years. Patient also gave history of difficulty in tongue movements, while speaking and eating food. His past medical and dental history were unremarkable. Patient gave no history of any deleterious habits. Extra orally no abnormalities were detected. Intra oral examination revealed a round immobile nodular swelling on lower left posterior region, extending from second premolar to second molar. Panoramic radiograph and occlusal radiograph were advised. Panoramic radiograph revealed well-defined radiographic mass extending from lower left second premolar to lower left second molar (figure 1). Occlusal radiograph confirmed the location of the swelling to be on the lingual surface with broad base (figure 2). Considering the clinical and radiographic findings, peripheral osteoma of mandible was considered. The bony mass was surgically excised with sufficient safety margins and later sent for histopathological investigation. The histopathological specimen revealed dense compact bone with little fibrous connective tissue stroma at the periphery. Osteoid cells were present. Hence a final diagnosis of peripheral osteoma of the mandible was considered.

Osteomas real prevalence is unknown, with no sex predilection. However mandibular osteomas are rare entity. ${ }^{1}$ Osteomas are usually asymptomatic, characterised with slow and continuous growth patterns. Traumas and infections are the causes to trigger excessive bone activity. ${ }^{2}$ However, in the present case patient did not have any history of trauma or infection. In radiological examination, peripheral osteomas appear as an oval-shaped radiopaque mass with welldefined margins and growing on a broad base, as described in our report. It can also have a stalk on the cortex. These lesions usually do not cause destruction of the adjacent bone as reported in our case. ${ }^{3}$

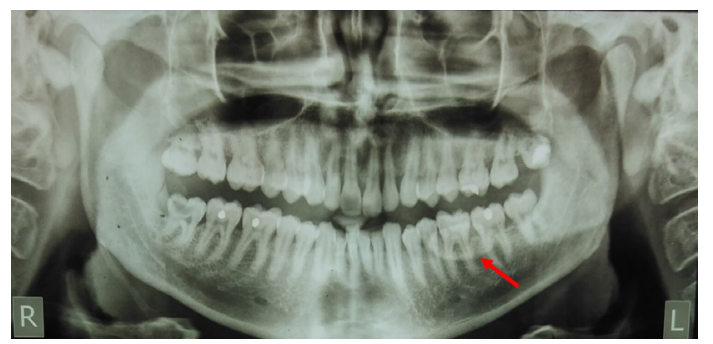

Figure 1 Panoramic radiograph revealing the radiopaque lesion.

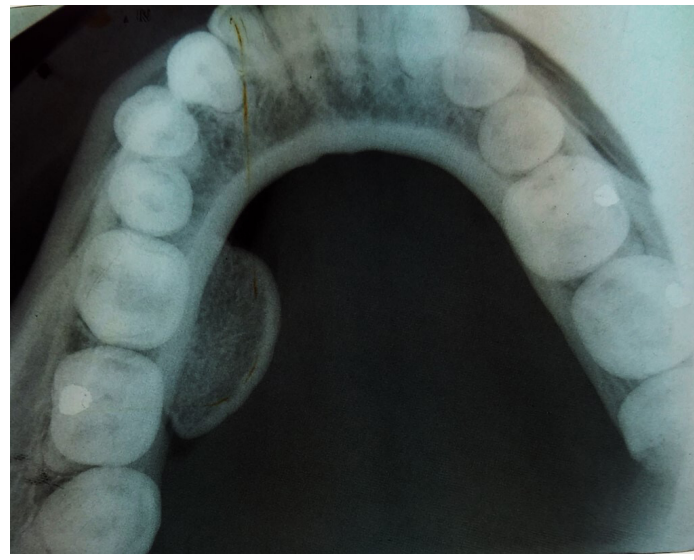

Figure 2 Occlusal radiograph showing the broad base of the bone mass and location of the lesion.

Peripheral osteoma should be differentiated from exostoses, osteoblastoma and osteoid osteoma, late-stage central ossifying fibroma or complex odontoma. Exostoses are bony excrescences that usually stop growing after puberty, differentiating them from osteomas. The borders of central ossifying fibromas are usually well defined with a thin radiolucent line which may separate it from the surrounding bone. A sclerotic border may be present in the bone next to the lesion. ${ }^{4}$

Surgical excision is the treatment of choice for osteomas. Resection of the lesion was done with a sufficient safety margin when the lesion was classified as 'true osteomas' based on the appropriate diagnosis. ${ }^{5}$ However, the lesions rarely show recurrence with no evidence of malignant

\section{Learning points}

Mandibular osteomas are rare and benign radiopaque lesion, which require both clinical and surgical attention, as it could be concern of speech, mastication and aesthetics of an individual.

- Radiographical and histopathological confirmation are mandatory in ruling it out from other similar types of radiopaque lesions of the jaw.

- Patients with osteomas should be evaluated for Gardner's syndrome. These patients may present with symptoms of rectal bleeding, diarrhoea and abdominal pain. The triad of colorectal polyposis, skeletal abnormalities and multiple impacted or supernumerary teeth is consistent with this syndrome. 
transformation. ${ }^{4}$ In the present case, the lesion was totally excised, and the patient was placed on follow-up.

Acknowledgements The authors would like to thank our Institution Melaka Manipal Medical College, our beloved Dean Professor Dr Abdul Rashid Hj. Ismail, and Professor Dr Sumanth Kumbargere Nagraj, Head of the Department, Department of Oral Medicine and Oral Radiology for their all time support.

Contributors VN and US helped in the conception and design, acquisition of data or analysis and interpretation of data and drafting the article or revising it critically for important intellectual content. PKR and RK gave final approval of the version to be published.

Funding The authors have not declared a specific grant for this research from any funding agency in the public, commercial or not-for-profit sectors.

Competing interests None declared.
Patient consent for publication Obtained.

Provenance and peer review Not commissioned; externally peer reviewed.

\section{REFERENCES}

1 Kaplan I, Nicolaou Z, Hatuel D, et al. Solitary central osteoma of the jaws: a diagnostic dilemma. Oral Surg Oral Med Oral Pathol Oral Radiol Endod 2008;106:e22-9.

2 Cutilli BJ, Quinn PD. Traumatically induced peripheral osteoma. Report of a case. Oral Surg Oral Med Oral Pathol 1992;73:667-9.

3 Chandra J, Prasad BR, Veena KM. Osteoma of the frontal bone: a case report. J Clin Diagn Res 2009;3:1426-30.

4 White SC, Pharoah MJ. "Benign tumors of the jaws," in Oral Radiology; Principles and Interpretation, chapter 21. St.Louis, Mo, USA: Mosby, 2004: 410-57.

5 Kamimura R, Fukumoto C, Hasegawa T, et al. A case of mandibular peripheral osteoma on the inferior border of the mandible. Oral Sci Int 2020;00:1-5.

Copyright 2020 BMJ Publishing Group. All rights reserved. For permission to reuse any of this content visit

https://www.bmj.com/company/products-services/rights-and-licensing/permissions/

BMJ Case Report Fellows may re-use this article for personal use and teaching without any further permission.

Become a Fellow of BMJ Case Reports today and you can:

- Submit as many cases as you like

- Enjoy fast sympathetic peer review and rapid publication of accepted articles

- Access all the published articles

- Re-use any of the published material for personal use and teaching without further permission

Customer Service

If you have any further queries about your subscription, please contact our customer services team on +44 (0) 2071111105 or via email at support@bmj.com.

Visit casereports.bmj.com for more articles like this and to become a Fellow 